\title{
LA CIUDAD VIEJA DE AARHUUS, DINAMARCA
}

\begin{abstract}
El señor Frans Blom ha obsequiado a este Instituto unas publicaciones danesas sobre los museos arquitectónicos de Dinamarca, para las cuals escribió la siguiente nota. Vemos por ella el cuidado que el Gobierno de actuel culto pais tiene con sus obras de arte $y$ la energía con que apoya toda labor para la conservación de su patrimonio histórico y artístico. El Instituto agradece la donación, y considera de interés publicar la mencionada nota.
\end{abstract}

Y Yy en Dinamarca dos museos, que tienen un carácter bastante espeI cial que los hace insólitos. E1 uno, en las afueras de la capital, Copenhague, está formado por un conjunto de casas, de fincas y ranchos, distinguiéndose cáda unidad por su edad o rasgos arquitectónicos, o por ser típica de determinada región del país.

En el otrom museo, en Aarhuus, la segunda ciudad de Dinamarca se ha reunido un grupo de casas de pueblo y de ciudad, que también, por su antigüedad o valor arquitectónico y artístico, pertenecen a la herencia cultural del pueblo danés.

Las leyes de protección de monumentos arquitectónicos de Dinamarca son muy estrictas, y el gobierno procura reforzarlas. Todos los edificios antiguos se ordenan en tres categorías: Edificios de primera son los que, por su edad e importancia histórica deben preservarse. Está rigurosamente prohibido tirarlos o hacerles alteraciones. Los arquitectos del $\mathrm{Mu}$ seo Nacional se ocupan de cualquier restauración y todos los gastos de mantenimiento son erogados por el gobierno. 
Los edificios de segunda clase tampoco pueden derrumbarse; están bajo la supervisión de los arquitectos del gobierno, el cual contribuye a los gastos de mantenimiento y preservación.

Bajo la tercera categoría se agrupan los edificios que tienen valor artístico o que han sido contruidos por un arquitecto de fama nacional.

Así se ha creado en Aarhuus una hermosa y vieja ciudad, trasladando a sus terrenos, antiguos y bellos edificios que tenían su asiento en distintas partes del país. Cada uno de estos edificios fué medido cuidadosamente, desbaratado piedra por piedra y vuelto a reconstruir exactamente como fué creado. Pero no se han concretado sólo a la concentración de los edificios, sino que han dedicado especial atención en amueblarlos, conservando propiedad y armonía en el estilo, sin escatimar esfuerzos para lograrlo. Por ejemplo: la casa de la botica de la ciudad vieja de Aarhuus, procede de un lugar, y muebles y decorados interiores fueron llevados de otro. Allí está también la casa del herrero; del tintorero; el edificio de la aduana, exhibiendo su auténtica y antañona belleza. Lo mismo se puede decir de la casa del taller del relojero y el vidriero. Se han reconstruido fielmente las primitivas fábricas de puros y sombreros, y allí está el viejo molino que mueven las aguas de un arroyo que atraviesa el corazón de la ciudad, y más adelante, la casa grande de un antiguto cabildo y vivienda del alcalde.

De todas partes del país se han llevado muebles, adornos, herramientas. Muchos objetos han sido comprados por el gobierno, pero más son los que ha cedido el pueblo. Porque el museo de la ciudad vieja es un orgullo del pueblo danés, y todo el mundo desea engrandecerlo y mejorarlo, para que los jóvenes puedan ver cómo vivían sus abuelos; para que los viejos no sientan nostalgía de su pasada juventud y para que los visitantes de países lejanos puedan darse una idea del desarrollo cultural del pueblo danés. 